\title{
Small-scale fishermen: Poverty as a challenge to achieve Sustainable Development Goals (SDGs) in Sunda Strait
}

\section{Nelayan skala kecil: Kemiskinan sebagai tantangan pencapaian Tujuan Pembangunan Berkelanjutan (SDGs) di Selat Sunda}

\author{
Yonvitner Yonvitner ${ }^{1,3 *}$, Hanif Wafi², Gatot Yulianto ${ }^{1}$, Mennofatria Boer', \\ \& Rahmat Kurnia ${ }^{1}$
}

${ }^{1}$ Department of Aquatic Resources Management, Faculty of Fisheries and Marine Science, Institut Pertanian Bogor

${ }^{2}$ Researcher in Environmental Division, Sucofindo

${ }^{3}$ Centre for Coastal and Marine Resources Studies (CCMRS), Institut Pertanian Bogor

Address: ${ }^{1,3}$ Jalan Raya Dramaga, Bogor, West Java, Indonesia 16680

${ }^{2}$ Jalan Raya Pasar Minggu Kaviliun 34, Jakarta, Indonesia 12780

E-mail: yonvitr@yahoo.com

Article History: Received 9 April 2020; Accepted 1 February 2021; Published Online 25 February 2021

\begin{abstract}
The poverty reduction indicator in SDGs also includes small-scale fisheries community groups. Smallscale fisheries' poverty can be measured by income, expenditure, and income, converted to minimum living consumption and village welfare standards. These research aims to study of fisherman income, and welfare level as an indicator of poverty status. The research was conducted at the fisheries landing port in the Sunda Strait during 2019 to collect fisheries data covering production, operational cost, and household expenditure costs. The results showed that most ship crew fishers and ship captains (74\%) were poor. Only $26 \%$ of the fishermen lived in no poverty status; however, all fishermen classified as high and medium welfare levels from the welfare indicator. Reducing poverty status (period 2020-2030) to be null (zero poverty) should be gradual with a yearly target. According to SDGs target, it needs comprehensive efforts to reduce poverty within ten years, with an average reduction of $7 \%$ per year until 2030. It means the government should implement the fishermen's poverty reduction as part of the national development target.
\end{abstract}

Keywords: poverty; small-scale fisheries; Sunda Strait; SDGs; welfare

\begin{abstract}
Abstrak
Kemiskinan nelayan skala kecil dapat diukur dari pendapatan, pengeluaran dan penerimaan yang kemudian dikonversi ke dalam kebutuhan hidup minimum dan standar kesejahteraan desa. Studi ini bertujuan untuk mengevaluasi tingkat pendapatan nelayan skala kecil dalam upaya mencapai SDGs sesuai dengan standar kebutuhan hidup minimum sebagai indikator kemiskinan. Penelitian yang dilakukan di pusat perikanan di Selat Sunda selama 2019 mengambil data mencakup hasil tangkapan nelayan, kebutuhan biaya operasional, dan kebutuhan biaya pengeluaran rumah tangga. Hasil penelitian menunjukkan bahwa sebagian besar 74\% nelayan anak buah kapal dan sebagian nahkoda berada dalam kondisi miskin. Sementara itu, hanya 26\% yang berada diatas batas kemiskinan dan dianggap mampu memenuhi kebutuhan hidup minimum; namun, dari indikator kesejahteraan, semua nelayan tergolong tingkat kesejahteraan tinggi dan sedang. Dalam penurunan kemiskinan (periode 2020-2030) hingga menjadi nol (zero poverty) perlu dilakukan secara bertahap dengan target tahunan. Menurut target SDGs, perlu upaya komprehensif untuk menurunkan prosentase kemiskinan dalam waktu sepuluh tahun dengan rata rata penurunan sebesar 7\% per tahun sampai 2030. Ini bermakna bahwa pemerintah harus mengimplementasikan pengurangan kemiskinan nelayan sebagai target pembangunan.
\end{abstract}

Kata Kunci: kemiskinan; nelayan skala kecil; Selat Sunda; SDGs; kesejahteraan

\section{Introduction}

Sustainable Development Goals (hereafter called SDGs) is to reduce poverty for all people to be no poverty; the point is that everyone has justice and access to be free from poverty. The spirit of SDGs is equality of life in various strata of society and reducing inequality. Also included in this group are 
the communities on the coast with fishing and marine services. The poverty of small-scale fisheries is not only due to declining stocks; it is also expected to be due to ecosystem degradation (Lynch et al. 2017), risk of vulnerability (Khatami et al. 2018), and policies. In Indonesian fisheries, fishery's business operators are small-scale fishers who reach 75\% (Yonvitner et al. 2020b) of total fishers. These small-scale fishers generally use small vessels under 30 Gross Tonnage (GT). The concept of small-scale fisheries refers to Law Number 7 of 2016 concerning the Protection and Empowerment of Fishermen, where fisheries that use vessels $<30 \mathrm{GT}$ are small-scale fisheries. The most significant proportion in small-scale fishers is the fishers group with vessel capacity $<10$ GT or both with and without a machine.

Fishers with $<30$ GT vessels generally make catches for 1-3 days in each fishing operation. In smallscale fisheries, there is also strata of position in the fishing process. Some fishers become captains, crew machine, and ship crew. The differences in position also have implications for differences in income and salary that they have. The amount of revenue depends on the number of catches obtained in each fishing operation; however, due to fishing operations that use the capital system at the owner's support, the total value's net income will be minus operating costs. This system's impact also causes a strong relation between patron ship crew and client (owner). As an impact of this system, the fishermen are often trapped in poor conditions because there is a period of low production or declining stock.

Small-scale fisheries operate in the Sunda Strait area in the State Fisheries Management Territory of the Republic of Indonesia (hereafter called WPPNRI) 572. This fisheries management territory has a potential stock of 588.60 thousand tons per year dominated by small pelagic fish (Kementerian Kelautan dan Perikanan 2014). The fishermen who operate in the WPPNRI 572 of the Sunda Strait will land their catches in Labuan Port in Pandeglang, Banten Province, and Lempasing Port, Lampung Province, a pelagic fish, and demersal species.

In addition to decreasing stock, the decline of fisher income can be triggered by catastrophic events such as the current Covid-19 or overfishing (Boer \& Aziz 2007). In this study conducted in the Sunda Strait, the tsunami's impact on Mount Krakatau's eruption was still affecting the community. Disasters, ecosystem damage on a global scale, and climate change further increase the fisheries' uncertainty and welfare in small-scale fisheries (Puspita et al. 2017), particularly in Sunda Strait. This uncertainty condition then causes fishers to be unable to increase their income and get trapped in poverty. Kusnadi (2002) states that poverty is a condition that must be accepted by fishermen because there is a connection with work that has to be as a fisherman. The habit of work as a fisherman provides little opportunity to pursue other jobs, so that income is only from fishing. Satria (2009) mentions that fishers' poverty tightens its relation to resources influenced by policies, access, and property rights. Salagrama (2006) states that fishers' poverty reflects their standard housing, facility, access, sanitation system, and basic needs, such as water for drinking, food supply, and transportation services.

Poverty also has been widely explained by the Organisation for Economic Co-operation and Development (2001), which stated poverty encompasses different dimensions of deprivation related to human capability, including consumption, food security, health, education, right, voice, security, dignity, and decent network. The income poverty approach was widely used in 1960 and closely associated with low income or consumption. In small-scale fisheries, poverty in the fishing community is widely acknowledged and accepted. Townsley (1998) stated that fishing communities, including small scale, are often characterized by overcapacity living conditions, inadequate services, low-level skill, asset, and income. In this context, the fishing community's poverty explains by the fisherman's income, the reflection of skill (position on board, where skill and assets domain showed), and fishing ground (days of fishing). The total income obtained will explain the level of poverty concerning SDGs.

There is no poverty or decrease in fishers' poverty, and it is the main target of national commitment. For this reason, data analysis and information regarding the income of small-scale fisheries must be carried out so that the implementation of SDGs in fisheries has a fact and evidence-based basis for policy. The program to bring about poverty reduction of small-scale fishers in Indonesia requires a holistic approach, beginning from the knowledge and food needs (Diz et al. 2019) of the community. 
This research will study fisherman income level to determine the community's level of poverty and welfare status. This income is used as the poverty threshold for the SDGs target in the fisheries community of no poverty and will be adaptable and operationally implemented to the community level.

\section{Research Method}

The study was conducted in May 2019 at two representing locations, the Sunda Strait, the Labuan Fishing Port in Banten, and the Lempasing Coast Fishing Port in Lampung (Figure 1). The fishers' data are production data for each fish species, vessel size, and fishing ground. Then the fishing community's socio-economic data are used to determine the consumption level and welfare. Fishers collected the ship crew, machine crew, and ship captain representing fishing vessel $<10$ GT and fishing vessel up to $>10$ GT. The fishing vessel size and category of fishers' classification refers to Fisheries and Marine Law Number 7 of 2016 concerning fishers' empowerment, fish farmers, salt entrepreneurs, and fishers' protection. The socio-economic data were collected using a questionnaire to the respondents who attend fishing operations. The total respondents selected were 30 fishers from both locations (Labuan and Lempasing). The limited number of respondents focuses on the statistics descriptive approach used in description and explanation (Walpole 1990). This research approach by quantitative data and analysis for production and socio-economic community.

Fishers generating income is a crucial variable reviewed to ensure that fishers obtain production and salary. Besides the income from fisheries activity, other economic activities also count as the fisher's total income. The analysis of fishers' income uses the following formula (Purnomo 1999):

$P_{\text {rt }}=$ Total income of the fishers (IDR)

$$
P_{r t}=P_{t 1}+P_{t 2}
$$

$P_{\mathrm{t} 1}=$ Income from fishing activity (IDR)

$P_{\mathrm{t} 2}=$ Income from non-fishing activity (IDR)

In addition to income, the calculation of the same expenditure for fishers was simultaneously done. In this assessment, the analysis expenditures consider consumption (food) and non-consumption (non-food). The formulation used to calculate the level of expenditure of a fishers' household is as follows (Purnomo 1999):

$$
\mathrm{C}_{\mathrm{rt}}=\mathrm{C}_{\mathrm{t} 1}+\mathrm{C}_{\mathrm{t} 2}
$$

$\mathrm{C}_{\mathrm{rt}}=$ Total expenditure of fishers (IDR)

$\mathrm{C}_{\mathrm{t} 1}^{\mathrm{t}}=$ The expenditure for consumption (food) (IDR)

$\mathrm{C}_{\mathrm{t} 2}=$ The expenditure for non-consumption (non-food) (IDR)

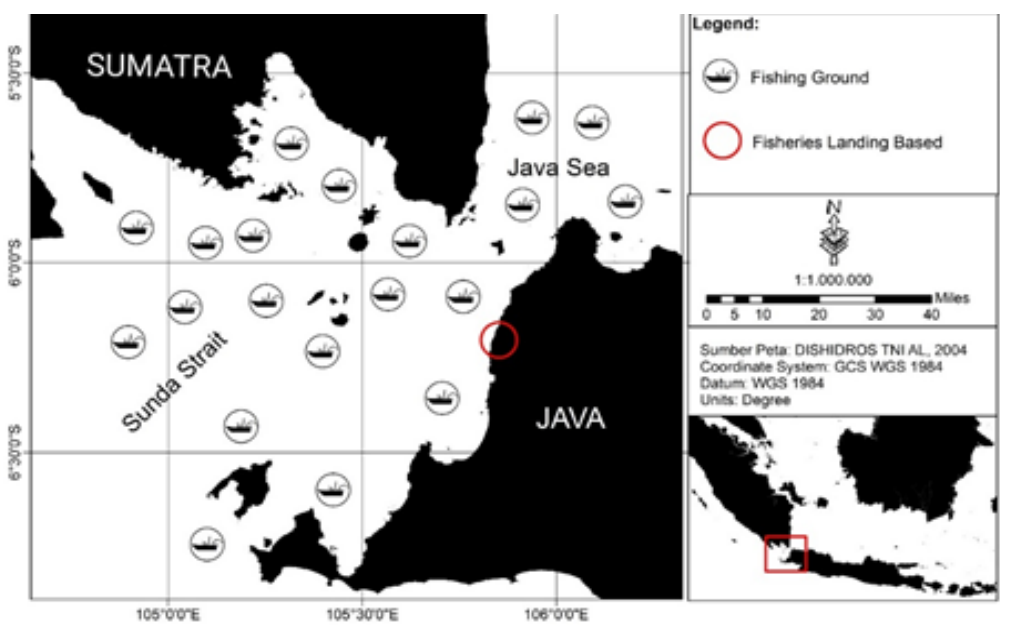

Figure 1.

Research location in Sunda Strait in two representative landing ports

Source: Yonvitner et al. (2020a) 
Assessment of fisher's poverty is needed to know the level of quality of life of fishers and their poverty level. Based on this assessment, we can measure the poverty status, including poor or not poor (above the poverty line). The value as the threshold or poverty limit is based on the income received compared with the minimum wage level (regency or city) and calorie adequacy (Sajogyo 2006). Based on the Governor of Banten Decree number 561/Kep.442-Huk/2017 dated 20 November 2017, which was set to take effect 1 January 2018 stated that the regency or city wage data in Pandeglang Regency amounts to 2.542.539 IDR per month. According to the Lampung Governor's decision 2018, the provincial minimum wage of Bandar Lampung City is 2.445.141 IDR per month (Disnaker Provinsi Lampung 2018). The Indonesian population's poverty threshold is assessed from the equivalent rice per capita consumption per year with local rice's price or value (Sajogyo 2006). According to Sajogyo (2006), the poverty criteria are then used as a threshold in determining the status of poverty of fishers (Table 1). The poverty assessment, according to the formulation by Sajogyo (2006):

\section{$\mathrm{Pk}=\mathrm{Prt} \div \mathrm{Jt}$ or Pks=Prt $\div \mathrm{Hb}$}

$\mathrm{Pk}=$ Revenue of fishers per kapita household/year (IDR)

Prt= Household revenue per year (IDR)

$\mathrm{Jt}=$ Total family (person)

$\mathrm{Pks}=$ Income or capita or equivalent rice $(\mathrm{kg})$

$\mathrm{Hb}=$ Rice price (IDR per $\mathrm{kg}$ )

Table 1.

Status, criteria, and threshold of poverty

\begin{tabular}{|c|c|}
\hline Status and criteria & Remark: Threshold \\
\hline Non-poor level & $\begin{array}{l}\text { All people whose per capita income per year is higher than the exchange } \\
\text { rate of } 320 \mathrm{~kg} \text { of rice or } 2.880 .000 \text { IDR per month (village) and higher than } \\
480 \mathrm{~kg} \text { of rice or } 5.280 .000 \text { IDR per month (city). }\end{array}$ \\
\hline $\begin{array}{l}\text { Poor level (food } \\
\text { sufficiency) }\end{array}$ & $\begin{array}{l}\text { If per capita income per year is lower than the exchange rate of } 320 \mathrm{~kg} \text { of } \\
\text { rice or } 2.880 .000 \text { IDR per month (village) and } 480 \mathrm{~kg} \text { of rice or } 5.280 .000 \\
\text { per month (city). }\end{array}$ \\
\hline $\begin{array}{l}\text { Extremely poor level } \\
\text { (not enough food) }\end{array}$ & $\begin{array}{l}\text { If per capita income per year is lower than the exchange rate of } 240 \mathrm{~kg} \text { of } \\
\text { rice or } 2.160 .000 \text { IDR (villages) and } 360 \mathrm{~kg} \text { of rice or } 3.960 .000 \text { IDR (cities). }\end{array}$ \\
\hline $\begin{array}{l}\text { The poorest } \\
\text { (destitute) }\end{array}$ & $\begin{array}{l}\text { If per capita income per year is lower than the exchange rate of } 180 \mathrm{~kg} \text { of } \\
\text { rice or } 1.620 .000 \text { IDR (villages) and } 270 \mathrm{~kg} \text { of rice or } 1.620 .000 \text { IDR (cities). }\end{array}$ \\
\hline
\end{tabular}

$$
\text { Source: Sajogyo (2006) }
$$

Based on Badan Pusat Statistik (2015) classification, a welfare analysis of the fishers was carried out using ten modified indicators of people's welfare. The welfare indicators used as analyzed are household income (IDR per month) of fishers, household consumption or expenditure (IDR per month), the state of residence of the fisherman, residence facilities, the health of household members, service to getting health services from medical personnel, family education, ease of getting transportation facilities, sense of security from the interference of crime, and social access from the community. A quantitative analysis is made through composite analysis with a multi-criteria scale approach-with use scoring of the data row. The scoring process results are shown as a composite value of welfare index with the following criteria a) score between 2.61-3.41 (high-level welfare), b) score between 1.81-2.60 (moderate level of welfare), and c) score between 1.00-1.80 (low welfare level).

\section{Results and Discussion}

The number of respondents in the research of fishermen welfare in Labuan and Lempasing was 30 people. The captain and the crew represent fishermen's position for a fishing vessel under $<10 \mathrm{GT}$ the sample, while the fishing vessel $>10$ GT respondent sample consists of the captain, machine crew, and ship crew. The total sample for fishers at vessel under $<10$ GT is eleven people with a Labuan composition of six people, and Lempasing of five people. Meanwhile, the fishermen who used fishing 
vessels $>10$ GT were 19 people with seven people in Labuan and 12 people in Leasing. Respondent structure at the research location present in Figure 2. Based on Figure 2, the total number of Labuan samples was $43.3 \%$ and Lempasing $56.66 \%$. Based on the ship's size, respondents from vessels under $<10$ GT were $36.6 \%$, and those using large vessels were $63.33 \%$. Respondents in Lempasing are extensive because of the greater fishery business capacity compared to Labuan.

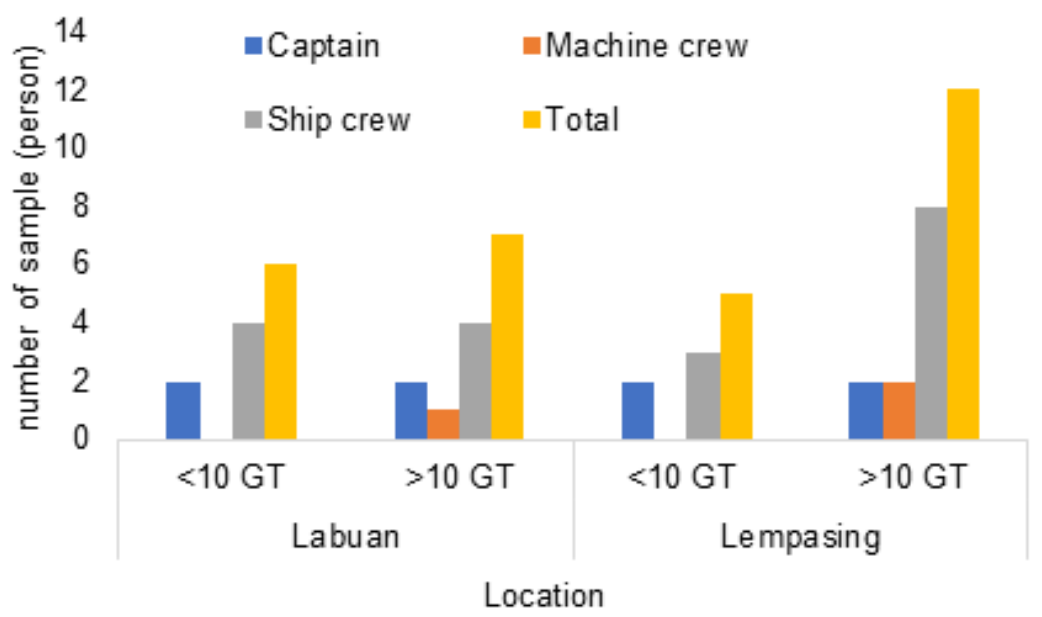

Figure 2.

Respondent profile in Labuan and Lempasing sampling site

Source: Primary data (2019)

\section{Fishing season and production}

Fishing activity in the Sunda Strait is carried out throughout the year, divided into three different seasons: peak production season, medium production season, and low production season. The largest production season is from May to August, while the lowest catch season is from November to February. In other months, the catch is relatively moderate or average both of peak and low production in so-called transitional seasons. Total production from the two landing sites, in the peak season production, is a total $1.045 \mathrm{~kg}$ per trip, medium season reaches $512 \mathrm{~kg}$ per trip, and low season is $201 \mathrm{~kg}$ per trip. The average catch per trip for each season show in Figure 3.

Based on Figure 3, production in the peak season is $103.08 \mathrm{~kg}$ per trip in Labuan fish landing port, $942.17 \mathrm{~kg}$ per trip, and $496.94 \mathrm{~kg}$ per trip in Lempasing, with an average of $523 \mathrm{~kg}$ per trip. In November-February, fish production in the low season is about $20 \%$ of the peak season's total catch. Besides the season impact, low production is also influenced by stock decreasing and increasing stock vulnerability (Ofori-Danson et al. 2013). Research conducted by Yonvitner et al. (2018) shows that fisheries' intrinsic vulnerability in the Sunda Strait tends to be high. The fishing practice must be done with a precautionary approach (Ardelia et al. 2017) to ensure stock sustainability.

\section{Fisherman Income}

The portion for vessel crews is distributed to the captain, machine crew, and ship crew in the production-sharing system. The ship crew's average profit share is two to three parts for the captain, 1.5 parts for the machine crew, and one part for the ship crew. The ship crew received the portion that was then further divided by the number of ship crew who participated in the fishing operation. That is why ship crew income remains low, and of the impact of the implementation of Law Number 16 of 1964 concerning Fishery Sharing Income (Yonvitner 2014). In addition, fisher's income was also influenced by the fishing vessels in fishing operations. Fishing vessels more than $>10 \mathrm{GT}$ catches, expenditure, and revenues are more generous than $<10$ GT in Labuan and Leasing. Profiles of fisher's income, expenditure, and income based on the vessels' size at the two locations are shown in Figure 4.

The differences in net income between the captain, the machine crew, and the ship crew have caused gaps and low ship crew income. Impacts arising from the small ship crew income sometimes trigger disputes 
between fishers (Sudaryanto 2009) or with the owner. Although the ship crew's cumulative income every month seems large, it does not reach the minimum standard of living requirements set, as shown in Table 2. According to the World Bank, poverty classification, all fisher's sampled in the Sunda Strait are not classified as poor. Meanwhile based on welfare classification, according to Badan Pusat Statistik (2015) fishers in Labuan and Lempasing, are classified as having high and medium welfare levels.

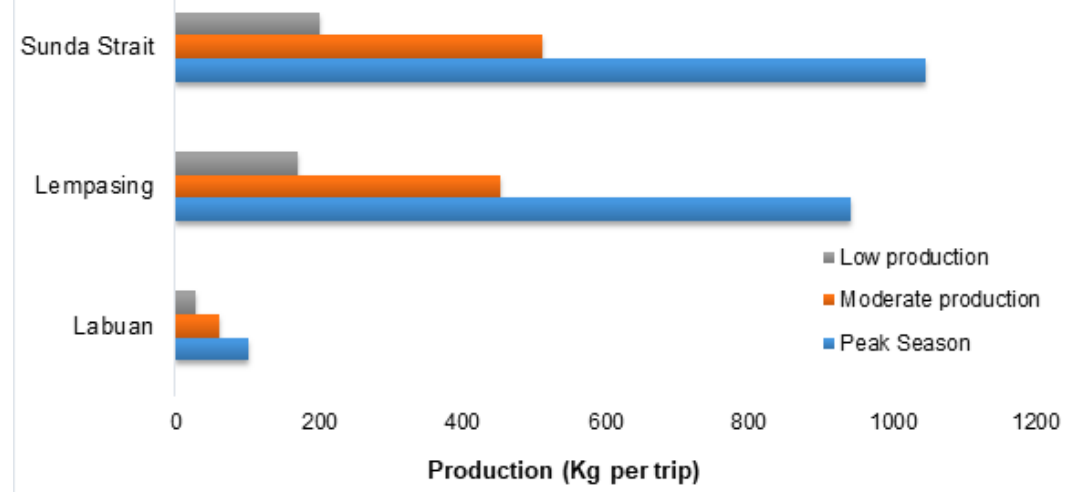

Figure 3.

Average of fish production per trip in each season

Source: Primary data 2019

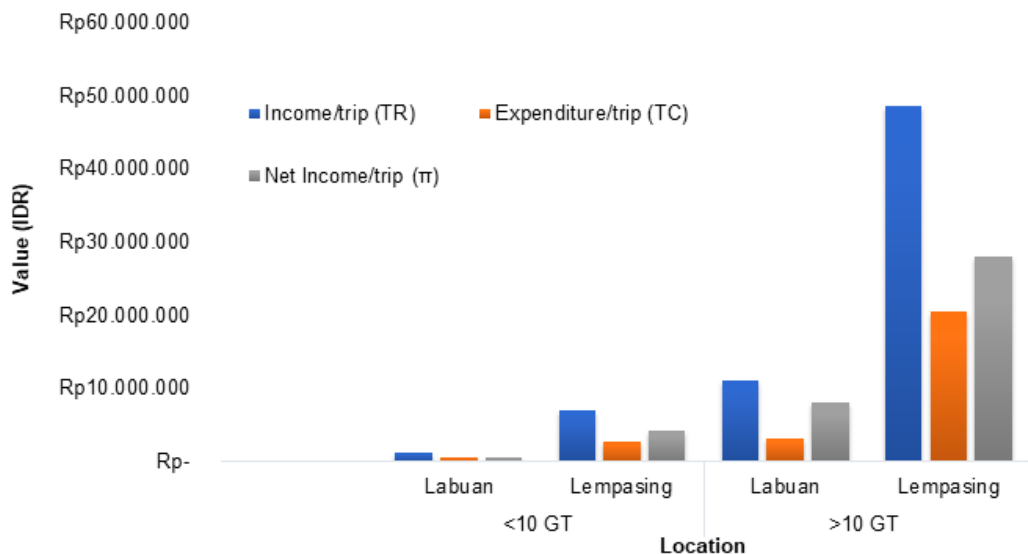

Figure 4.

Fisherman income value in Labuan and Lempasing

Source: Primary data 2019

The fishing operation using a boat with a size up to $>10$ GT use cantrang gear (Suwarso et al. 2017). They usually obtain more outstanding production and income than other ship crew or other fishing vessels. Captain and ship crew, who use small vessels or less than $<10$ GT have meager income and are near the poverty line. In general, catches on large vessels up to $>10$ GT are more considerable than smaller vessels $<10$ GT in both locations studied.

\section{Margin Income}

The average income of fishers is higher in the peak season and for large vessels (up to $>10$ GT). The highest income of fishers is in the peak season, about 10.967.722 IDR per month, and the lowest in the dry season is -2.184 .242 IDR per month on the small-scale boat captain. The income earned by fishermen is used for daily spending on household needs. Fisher's family expenditure is assumed to be the same every month, according to this study. The highest expenditure is large-scale boat skipper fishers in Labuan fish landing port at 550.000 IDR per month, and the lowest expenditure on smallscale boat fishers in Lempasing fish landing port 1.461 .389 per month.

The margin of monthly income and expenditure of fisher's households can be used for savings. The fact is that, when there is a margin, fishers use it for purposes other than household needs, such as 
shopping for commercial goods. Fishers with higher income levels on large-scale fishing vessels $(>10 \mathrm{GT})$ are those who have the potential to have more savings each month. The saving budget estimation by all fishers every month reaches as much as 71.265 IDR per month. The others at smallscale fishing vessels do not have margin allocations to saving.

Table 2.

The income average of fishers from sharing system in each vessel in Lampung and Labuan

\begin{tabular}{lclrc}
\hline Location & $\begin{array}{c}\text { Gross Tonnage } \\
\text { (GT) }\end{array}$ & Position & $\begin{array}{r}\text { Average income } \\
\text { (IDR per month) }\end{array}$ & Fishing gear \\
\hline \multirow{2}{*}{ Labuan } & \multirow{2}{*}{ <10 GT } & Captain & $2.123 .516,27$ & Apolo net \\
& & Ship crew & $1.641 .914,68$ & Payang \\
Lempasing & \multirow{2}{*}{ <10 GT } & Captain & $2.858 .147,22$ & Payang \\
& & Ship crew & $1.466 .797,53$ & Purse seine \\
Labuan & \multirow{2}{*}{$* 10 \mathrm{GT}$} & Captain & $4.771 .055,55$ & Rampus net \\
& & Crew machine & $2.685 .714,28$ & - \\
& & Ship crew & $1.875 .952,38$ & - \\
Lempasing & \multirow{3}{*}{$* 10 \mathrm{GT}$} & Captain & $4.125 .763,03$ & Payang \\
& & Crew machine & $3.282 .424,24$ & Cantrang \\
& & Ship crew & $2.271 .708,16$ & - \\
\hline
\end{tabular}

Unbalanced income and expenditure can cause difficulties and sustainability of fishers' household and lead to poor conditions in the long term. Government policies should be addressed to ensure that fishers' income is equal to minimum living standards or decent living standards. If the need for decent living is fulfilled, it can be classified as not poor, even though there are differences in income from real expenditure and decent living limits; however, it must ensure that the value obtained is higher than the poverty line limit.

During the peak season (May-August), all vessels' income in all landing locations was high, while, in the midseason or season transition, the catch can also offset operational costs; however, during the low season, production from fishing provides low income from operating costs. As a result, income margins become minus, leading to poor status. The poverty gap will be more generous when there is no side income or having many family members (Harahap 2013). If seen from the average value, the revenue value is still positive for all categories of vessels and all places, namely Labuan and Leasing. On the other hand, fishers' incomes of vessels under $<10$ GT are low from the expenditure for the fishing master in Labuan and Leasing. The end crew's income at the two locations on a vessel up to $>10$ GT operating in the Sunda Strait is lower than a captain.

According to Sajogyo (2006), in general, fishers who are not classified as poor are the captain and crew machine on fishing vessels compared with the minimum income limit for a decent living to $>10$ GT. For the ship crew's others, their work classifies as poor because of low income from minimum living needs. At the income threshold on the extremely poor line, from the captain, ship crew in Labuan and ship crew in Lempasing are classified as destitute (the poorest) on vessels under $<10 \mathrm{GT}$, while on a vessel up to $>10$ GT, only ship crew in Labuan are classified as the poorest (destitute).

Poverty is a condition where fishermen's income is insufficient to meet the minimum living needs in one month. Based on the poverty classification by Sajogyo (2006), small-scale fishers who landed the results in Labuan and Lempasing were $27 \%$ classified as not poor, $33 \%$ were poor, and $30 \%$ classified as extremely poor, and 10\% classified as destitute (Figure 5). From this composition, as not poor fishers are ship crew, crew machine, and captain. Poverty in SDGs reflects the lack of access to resources and markets (Said \& Chuenpagdee 2019). Although the production sharing system is applied, in several places such as Nabire (Tuharea 2015) and Sibolga (Argawansyah 2019) have a different situation, the distribution system according to community habits is more beneficial for ship 
crew. In the fisheries system at Sunda Strait, the fisheries business aims more to strengthen people's food than a long-term business (Susanto et al. 2020). According to the duties and responsibilities of fishing businesses in the Sunda Strait, the ratio of poverty groups is present in the following figure.

Based on the calculation of poverty in the Sunda Strait and several surrounding areas, poverty status, in general, is found at all levels in most coastal areas of Indonesia (Agunggunanto 2011). Fishers who are poor and extremely poor are vulnerable and high-risk groups to live correctly. Poverty conditions that occur were also caused by inequitable distribution of results (Retnowati 2011) and the absence of commitment as evidence (Andriani 2018) when the fishing process began. According to the World Bank (2019) poverty classification, all fishermen sampled in the Sunda Strait not classified as poor. Meanwhile, fishers in Labuan and Lempasing classify as having high and medium welfare levels based on welfare classification (Badan Pusat Statistik 2015). Two assessment indicators provide the conclusion that poor fishes have a moderate level of welfare. Therefore, we need improvements in policies and governance (Coulthard et al. 2011) to improve lives free from poverty with high welfare. According to Badan Pusat Statistik (2015), fisher's welfare calculation is present in Figure 6.

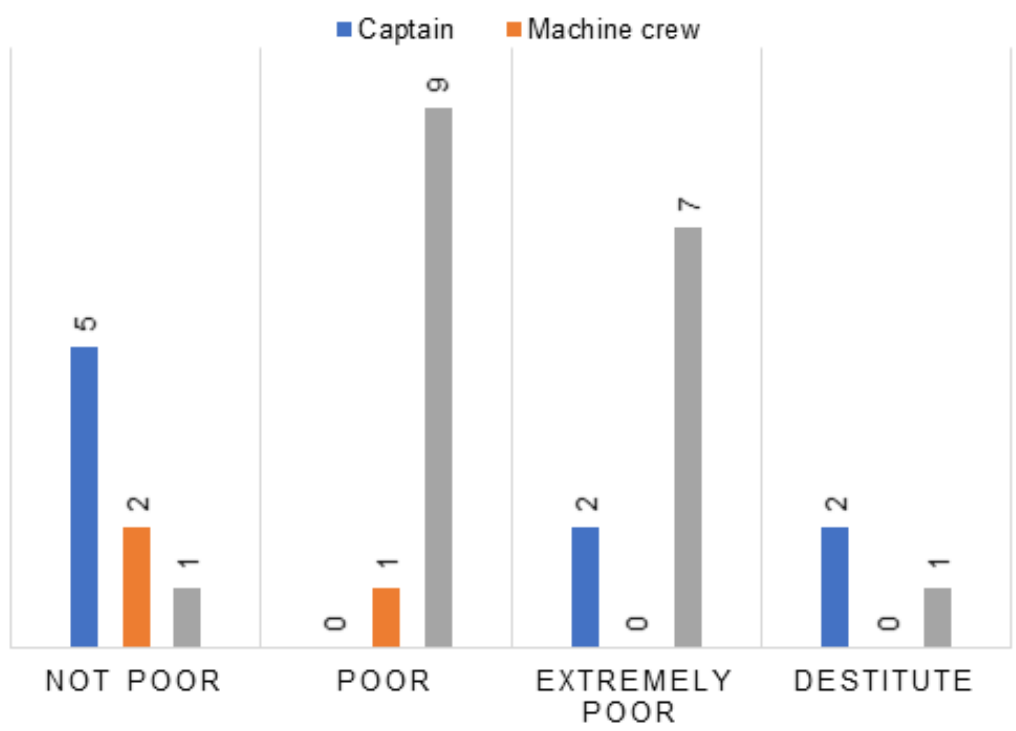

Figure 5.

Poverty status of fishers on small scale fisheries in Sunda Strait Source: Primary data 2019

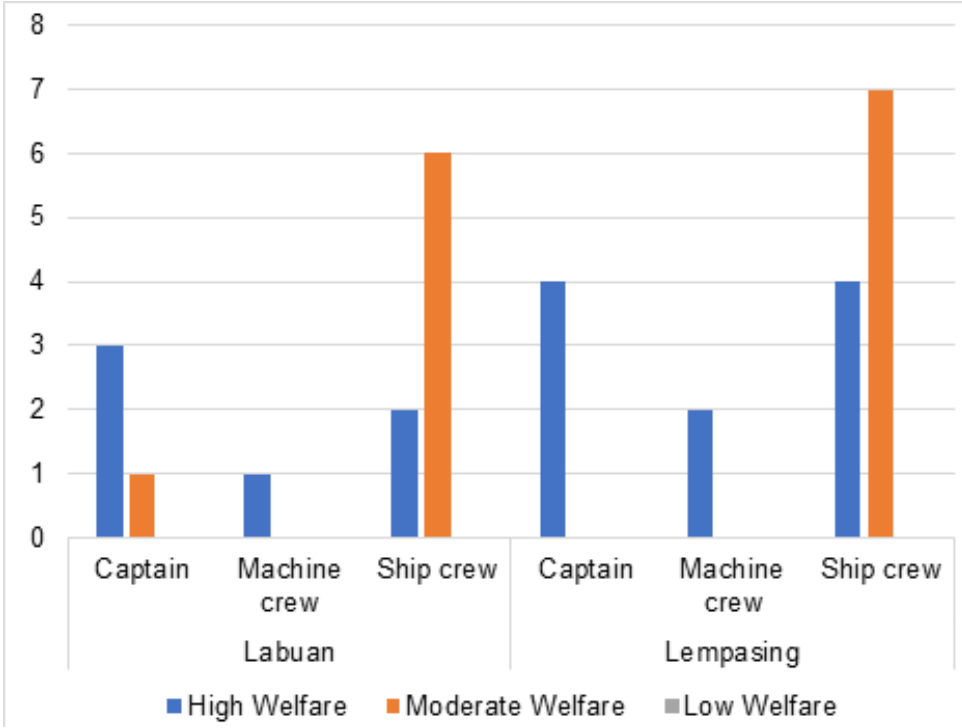

Figure 6.

Welfare level of fishers in Sunda Strait based on Badan Pusat Statistik (2015) criteria Source: Primary data 2019 
The poverty gap is the difference in income with the average poverty line according to the MSE standard (district minimum wage). The poverty gap index sees the proportion of the gap value in the rupiah value and the fishermen's poverty line percentage. The more significant the difference in income value that is small from the poverty line, the more significant the poverty gap and the most enormous poverty gap assessment results are found in ship crew fishers on small scale vessels, ranging from 900.624 IDR (-35.42\%) to 978.343 IDR (-40.01\%). Conversely, non-minus income values can be a non-poverty gap because income values are higher than the poverty line. The most considerable value of the non-poverty gap is found in skipper fishers on large scale vessels, ranging from 1.680.622 IDR (68.72\%) to 2.228.517 IDR (87.65\%). The visible gap shows that the structuring of positions on capture (Juliantono \& Munandar 2016) and port rent hunters (Humaedi 2017) contributed to perpetuating poverty and income differentials.

Concerning SDGs, "no poverty," fisheries business activities as a source of the economic community must be able to ensure that no community lives poor or even destitute in 2030. If the fisher's income value is limited to poor living criteria, the fisher's poverty reduction program must be the main target of development. This target must also be integrated through a poverty reduction strategy program that involves livelihood, fisheries management, and poverty (Walmsley et al. 2006). Within $10 \%$ of fisher's classified as destitute, and 30\% classified as extremely poor, $33 \%$ classified as poor, and only $26 \%$ live decently. The total cumulatively reaching $74 \%$ of fisher's who catch fish in the Sunda Strait live below the poverty line.

Policies are needed as a transformation step (Widodo 2011) consistently to achieve SDGs to reduce the poverty level. Some efforts to achieve no poverty in small-scale fisheries (Bene 2004) in the Sunda Strait area to acknowledge fishers' profession as an official profession that small-scale fisher recognize. Secondly, strengthen business ability, capacity, and fisheries' capability through fiscal reform (Mohhammed et al. 2018). Third, strengthen the added value of fisheries business by supporting the industry and fisheries business innovation. Fourth is to improve the ecosystem and the application of close season to ensure that fish stock monitoring efforts are also carried out to increase and catches increase (McClanahan 2010). Fifth, namely giving fisher's equal access to resources and catch allocation (Tain 2013). The sixth is to strengthen research and development in fisheries, such as international partnerships (Hiruy \& Eversole 2020). With the six steps above, it is expected that the status of the dominant fisher's classified as poor can be improved in the SDGs strengthening program. So that small-scale fisheries, particularly ship crew, also has benefited from the goals of sustainable development target.

\section{Conclusion}

Poverty research is needed both macro and micro in assessing the contribution of information about fisherman poverty status related to SDG. Studies in small-scale fisheries in the Sunda Strait show that fishermen's highest income is usually obtained during the peak season (large catches). While in the transition season or west season, the catch tends to be small so that the income is also small. However, if it is averaged monthly, small-scale fishers' income in the Sunda Strait is quite good. The poverty index from the consumption level found that $27 \%$ of fishers were poor, $33 \%$ were poor, $30 \%$ were abysmal, and $10 \%$ were destitute. Meanwhile, based on the BPS welfare index, it is seen that $53 \%$ classify as high welfare, and 47 classify as moderate welfare level.

The conclusion is generally known that small-scale fishers from fishing efforts are good enough and are approaching the community's necessities from the community from province minimum income, but less than the World Bank threshold. For this reason, we need to consider the quality of life in terms of environmental health and sanitation in the fish landing area. Reducing poverty in SDGs changes the status from destitute to poor, and poor to not poor; need ten years to reduce poverty with an average target of about $7 \%$ per year. This process was prepared in a draft model of fisherman poverty deconstruction in small scale fisheries. The poverty level and target reduction in Sunda Strait is a small view of Indonesia fisheries fact, where small scale fisheries dominated more than $75 \%$. 


\section{Acknowledgment}

Thank you to the MSP Laboratorium research team members who worked under coordinating the research program funded by LPPM IPB from the 2018 Simlimtabmas fund for the PDUPT scheme with the Research Grant Program contract number 4153/IT3.L1.PN/ 2019 prepared by the Ministry of Research Technology and Higher Education Republic Indonesia.

\section{References}

Agunggunanto EY (2011) Analisis kemiskinan dan pendapatan keluarga nelayan kasus di Kecamatan Wedung Kabupaten Demak, Jawa Tengah, Indonesia. Dinamika Ekonomi Pembangunan 1 (1):50-58. https://doi.org/10.14710/jdep.1.1.50-58.

Andriani Y (2018) Pola bagi hasil perikanan tangkap di Kota Karang Bandar Lampung. Thesis, Universitas Lampung, Bandar Lampung.

Ardelia V, Boer M, \& Yonvitner Y (2017) Precautionary approach dalam pengelolaan sumberdaya ikan tongkol (Euthynnus affinis, Cantor 1849) di Perairan Selat Sunda. Journal of Tropical Fisheries Management 1 (1):33-40. https://doi.org/10.29244/jppt.v1i1.20151.

Argawansyah C (2019) Perlindungan hukum terhadap nelayan pemilik dan nelayan penggarap dalam perjanjian bagi hasil perikanan (Studi masyarakat nelayan Kota Sibolga). Dissertation, Universitas Muhammadiyah Sumatera Utara, Medan.

Bene C (2004) Poverty in Small-Scale Fisheries: A Review and Some Further Thoughts. In: Neiland AE \& Béné C (eds). Poverty and Small-Scale Fisheries in West Africa. German: Springer.

Badan Pusat Statistik (2015) Indikator Kesejahteraan Rakyat 2015. Jakarta: Badan Pusat Statistik.

Boer M \& Aziz KA (2007) Gejala tangkap lebih perikanan pelagis kecil di Perairan Selat Sunda. Jurnal Ilmu-Ilmu Perairan dan Perikanan Indonesia 14 (2):167-172.

Coulthard S, Johnson D, \& McGregor JA (2011) Poverty, sustainability, and human wellbeing: A social wellbeing approach to the global fisheries crisis. Global Environmental Change 21 (2):453-463. https://doi.org/10.1016/j.gloenvcha.2011.01.003.

Disnaker Provinsi Lampung (2018) Upah Minimum Provinsi Lampung. Bandar Lampung: Dinas Tenaga Kerja.

Diz D, Morgera E, \& Wilson M (2019) Marine policy special issue: SDG synergies for sustainable fisheries and poverty alleviation. Marine Policy 110 (2019):1-2. https://doi.org/10.1016/j. marpol.2017.08.020.

Harahap SA (2003) Analisis masalah kemiskinan dan tingkat pendapatan nelayan tradisional di Kelurahan Nelayan Indah Kecamatan Medan Labuan Kota Medan. Thesis, Universitas Sumatera Utara, Medan.

Humaedi MA (2017) Kemiskinan nelayan: Studi kasus penyebab eksternal dan upaya revitalisasi tradisi pengentasannya di Kaliori, Rembang, Jawa Tengah. Jurnal Sosial Ekonomi Kelautan dan Perikanan 7 (2):193-206. https://doi.org/10.15578/jsekp.v7i2.5685.

Hiruy K \& Eversole R (2020) The contribution of research for development to the sustainable development goals: Lessons from fisheries research in Southeast Asia and the Pacific Islands countries. International Journal of Sustainable Development \& World Ecology 27 (2): 153166. https://doi.org/10.1080/13504509.2019.1697972.

Juliantono FJ \& Munandar A (2016) Fenomena kemiskinan nelayan: Perspektif teori Strukturasi. Politik: Jurnal Kajian Politik dan Masalah Pembangunan 12 (2):1857-1866.

Kementerian Kelautan dan Perikanan (2014) Potensi dan Tingkat Pemanfaatan Sumberdaya Ikan di Wilayah Pengelolaan Perikanan Republik Indonesia (WPP RI). Jakarta: Ref Graphika.

Khatami AM, Yonvitner Y, \& Setyobudiandi I (2018) Tingkat kerentanan sumberdaya ikan pelagis kecil berdasarkan alat tangkap di perairan Utara Jawa. Journal of Tropical Fisheries Management 2 (1):19-29. https://doi.org/10.29244/jppt.v2i1.25318.

Kusnadi MA (2002) Konflik Sosial Nelayan, Kemiskinan dan Perebutan Sumber Daya Perikanan. Yogyakarta: LKiS Pelangi Aksara. 
Lynch AJ, Cowx IG, Fluet-Chouinard E, Glaser SM, Phang SC, Beard TD, Bower SD, Brooks JR, Bunnell DB, Claussen JE, Cooke SJ, Kao YC, Lorenzen K, Myers BJE, Reid AJ, Taylor JJ, \& Youn S (2017) Inland fisheries-invisible but integral to the UN sustainable development agenda for ending poverty by 2030. Global Environmental Change 47 (2017):167-173. https://doi.org/10.1016/j.gloenvcha.2017.10.005.

McClanahan TR (2010) Effects of fisheries closures and gear restrictions on fishing income in a Kenyan coral reef. Conservation Biology 24 (6):1519-1528. https://doi.org/10.1111/j.15231739.2010.01530.x.

Mohammed EY, Steinbach D, \& Steele P (2018) Fiscal reforms for sustainable marine fisheries governance: Delivering the SDGs and ensuring no one is left behind. Marine Policy 93 (2018):262-270. https://doi.org/10.1016/j.marpol.2017.05.017.

Organisation for Economic Co-operation and Development (2001) Developing Action Committees Guideline on Poverty Reduction. France: OECD.

Ofori-Danson PK, Sarpong DB, Sumaila UR, Nunoo FK, \& Asiedu B (2013) Poverty measurements in small-scale fisheries of Ghana: A step towards poverty eradication. Journal: Current Research Journal of Social Sciences 5 (3):75-90.

Puspita R, Boer M, \& Yonvitner Y (2017) Tingkat kerentanan ikan tembang (Sardinella fimbriata, Valenciennes 1847) dari kegiatan penangkapan dan potensi keberlanjutan di Perairan Selat Sunda. Journal of Tropical Fisheries Management 1 (1):17-23. https://doi.org/10.29244/jppt. v1i1.20149.

Purnomo H (1999) Tingkat kesejahteraan keluarga nelayan di Desa Sungai Buntu, Kecamatan Pedes, Kabupaten Karawang. Undergraduate Thesis, Institut Pertanian Bogor, Bogor.

Retnowati E (2011) Nelayan Indonesia dalam pusaran kemiskinan struktural (Perspektif sosial, ekonomi dan hukum). Perspektif 16 (3):149-159. https://doi.org/10.30742/perspektif. v16i3.79.

Said A \& Chuenpagdee R (2019) Aligning the sustainable development goals to the small-scale fisheries guidelines: A case for EU fisheries governance. Marine Policy 107 (2019):103599. https://doi.org/10.1016/j.marpol.2019.103599.

Salagrama V (2006) Trends in Poverty and Livelihoods in Coastal Fishing Communities of Orissa State, India (No. 490). Rome: Food and Agriculture Organisation.

Satria A (2009) Ekologi Politik Nelayan. Yogyakarta: LKiS Pelangi Aksara.

Sajogyo (2006) Ekososiologi: Deideologisasi Teori, Restrukturisasi Aksi. Bogor: Cindelaras Pustaka Rakyat Cerdas.

Sudaryanto A (2009) Praktik bagi hasil perikanan di kalangan nelayan Pandangan Wetan, Rembang, Jawa Tengah. Mimbar Hukum 21 (3):522-537.

Suwarso S, Wudianto W, \& Atmaja SB (2017) Perubahan upaya dan hasil tangkapan ikan pelagis kecil di sekitar Laut Jawa: Kajian paska kolaps perikanan pukat cincin besar. Bawal: Widya Riset Perikanan Tangkap 2 (1):17-26. https://doi.org/10.15578/bawal.2.1.2008.17-26.

Susanto A, Hamzah A, Irnawati R, Nurdin HS, \& Supadminingsih FN (2020) Peran sektor perikanan tangkap dalam mendukung ketahanan pangan perikanan di Propinsi Banten. Leuit (Journal of Local Food Security) 1 (1):9-17.

Tain A (2013) Penyebab kemiskinan rumah tangga nelayan di wilayah tangkap lebih Jawa Timur. Jurnal Humanity 7 (1):1-10.

Townsley P (1998) Aquatic Resource and Sustainable Rural Livelihoods. In Carney D (ed). Sustainable Rural Livelihood: What Contribution Can We Make? London: Departement for International Development.

Tuharea F (2015) Perlindungan hukum terhadap nelayan tradisional dalam perjanjian bagi hasil perikanan antara pemilik kapal dengan nelayan kecil di Kabupaten Nabire. Legal Pluralism: Journal of Law Science 5 (2):273-298.

Walpole (1990) Pengantar Statistika. Jakarta: Gramedia Pustaka Utama.

Walmsley S, Purvis J, \& Ninnes C (2006) The role of small-scale fisheries management in the poverty reduction strategies in the Western Indian Ocean Region. Ocean \& Coastal Management 49 (11):812-833. https://doi.org/10.1016/j.ocecoaman.2006.08.006. 
World Bank (2019) World Bank country and lending groups. [Accessed 15 January 2021]. https:// datahelpdesk.worldbank.org/knowledgebase/articles/906519.

Widodo SK (2011) Dinamika kebijakan tentang perikanan dan transformasi budaya nelayan Pantai Utara Jawa. Sabda: Jurnal Kajian Kebudayaan 6 (1):30-39. https://doi.org/10.14710/ sabda.6.1.30-39.

YonvitnerY (2014) Rekonstruksi UU sistem bagi hasil perikanan pro nelayan kecil. Risalah Kebijakan Pertanian dan Lingkungan: Rumusan Kajian Strategis Bidang Pertanian dan Lingkungan 1 (3):192-196.

Yonvitner Y, Boer M, Akmal SG, \& Andi IS (2018) Kerentanan intrinsik dan risiko pemanfaatan perikanan: Analisis berbasis data poor untuk pengelolaan berkelanjutan. Journal of Tropical Fisheries Management 2 (2):54. https://doi.org/10.29244/jppt.v2i2.27369.

Yonvitner Y, Boer M, \& Ardelia V (2020a) A multi-criteria approach and sustainability index as a consideration on torpedo scad fisheries management in Sunda Strait. Jurnal Ilmiah Perikanan dan Kelautan 12(1):48-58. https://doi.org/10.20473/jipk.v12i1.16360.

Yonvitner Y, Yuliana E, Yani DE, Setijorini LE, Santoso A, Boer M, Kurnia R, \& Akmal SG (2020b) Fishing gear productivity-related fishing intensity and potency of stock vulnerability in Sunda strait. In: IOP Conference Series: Earth and Environmental Science 404 (1). IOP Publishing. 